Case Reports in Gastroenterology
Case Rep Gastroenterol 2021;15:22-27

DOI: 10.1159/000510163

Published online: January 21, 2021

(C) 2021 The Author(s)

Published by S. Karger AG, Base

www.karger.com/crg

This article is licensed under the Creative Commons Attribution-NonCommercial 4.0 International License (CC BY-NC) (http://www.karger.com/Services/OpenAccessLicense). Usage and distribution for commercial purposes requires written permission.

\title{
Crowned Dens Syndrome Occurring after Endoscopic Submucosal Dissection for Early Gastric Cancer
}

\author{
Takeshi Okamoto Takashi Ikeya Katsuyuki Fukuda \\ Department of Gastroenterology, St. Luke's International Hospital, Tokyo, Japan
}

\section{Keywords}

Anterior cutaneous nerve entrapment syndrome · Abdominal pain · Endoscopy ·

Complications - Case report

\begin{abstract}
Crowned dens syndrome (CDS) is a rare form of pseudogout which causes acute neck pain due to calcium pyrophosphate dehydrate deposition surrounding the odontoid process, commonly causing neck pain with rigidity. While invasive procedures such as surgery are known to present a risk of acute pseudogout, reports of occurrence after endoscopic procedures are scarce. We report the case of a 75-year-old man who presented with sudden neck pain after endoscopic submucosal dissection (ESD) for gastric cancer. He could nod but could not rotate his head. Computed tomography showed calcifications surrounding the odontoid process consistent with CDS. Prolonged dietary restrictions and proton pump inhibitor use following the ESD procedure may have caused hypomagnesemia, a precipitating factor for CDS. We prescribed colchicine $1 \mathrm{mg} /$ day and symptoms resolved completely in 3 days. This is the first report of CDS after ESD. CDS should be included in the differential diagnosis of neck pain after endoscopic procedures.

(c) 2021 The Author(s)

Published by S. Karger AG, Basel
\end{abstract}

\begin{tabular}{ll}
\hline & Takeshi Okamoto \\
Department of Gastroenterology & St. Luke's International Hospital \\
& $9-1$ Akashicho, Chuo-ku, Tokyo 104-8560 (Japan) \\
okamotot@luke.ac.jp
\end{tabular}




\section{Case Reports in Gastroenterology}

Case Rep Gastroenterol 2021;15:22-27

DOI: 10.1159/000510163

(c) 2021 The Author(s). Published by S. Karger AG, Basel www.karger.com/crg

Okamoto et al.: Crowned Dens Syndrome Occurring after Endoscopic Submucosal Dissection for Early Gastric Cancer

\section{Introduction}

Pseudogout, first described by Kohn et al. [1] in 1962, refers to acute gout-like attacks of synovitis due to calcium pyrophosphate dehydrate (CPPD) crystals. Any site can be involved, although the knees and wrists are most commonly affected. Old age is the strongest risk factor, while other risks include prior joint damage, recent surgery, hemochromatosis, hyperparathyroidism, hypomagnesemia, dehydration, and the use of diuretics [2]. Definite diagnosis requires the visualization of CPPD crystals in synovial fluid but plain radiographs can detect sizeable CPPD deposits [2, 3].

Crowned dens syndrome (CDS) is a rare form of pseudogout which causes acute neck pain due to CPPD deposition surrounding the odontoid process [4]. While neck pain with rigidity accompanied by fever is the most common presentation, other associated symptoms include headache, shoulder pain, dizziness, and jaw claudication [5].

While invasive procedures such as surgery are known to present a risk of acute pseudogout, reports of occurrence after endoscopic procedures are scarce [6-9]. Here we present the case of CDS which occurred after endoscopic submucosal dissection (ESD) for early gastric cancer.

\section{Case Report/Case Presentation}

A 75-year-old Japanese man presented with sudden neck pain. His medical history was only remarkable for duodenal bulb resection due to duodenal ulcer perforation over 30 years ago. He was an occasional drinker and had never smoked cigarettes. Three months before presenting with neck pain, 2 very similar gastric lesions were discovered on routine endoscopy. One lesion was located on the anterior wall of the lower body and the other at the fundus of the stomach. Both were yellow with visible irregular vessels and only about $4-5 \mathrm{~mm}$ in diameter (Fig. 1). Biopsy of the first revealed cell atypia suspicious of adenocarcinoma, while the second was negative for malignancy. ESD was performed for the first lesion without complications and the patient was discharged 6 days after the procedure on oral proton pump inhibitors (PPIs), with instructions to maintain a soft foods diet for 2 weeks. The pathological diagnosis was gastric adenocarcinomas of the fundic gland type.

Repeat biopsy of the second lesion on follow-up endoscopy 2 months later revealed malignant cells, with similar pathology as the first lesion. ESD for the second lesion was performed 3 months after the first ESD. The post-procedural course was again uneventful. The patient was discharged 3 days after the ESD, again with PPIs and instructions to maintain a soft foods diet.

Both ESDs were performed by the same endoscopist (T.O.) using the same endoscope (GIF-Q260J, Olympus Medical Systems, Tokyo, Japan). Midazolam and pethidine were used as sedation in both cases. Second-look endoscopies were performed the day after both procedures, revealing no complications. Intravenous cefmetazole and omeprazole were given for 3 days, after which esomeprazole was given orally. The same type and amount of hydration was given. Pathology in both procedures revealed en bloc resection of a gastric adenoma of the fundic gland type limited to the mucosal layer (T1a), with negative margins and no vascular or lymphatic invasion. Both times, the patient was discharged on oral PPIs and dietary restrictions. The only notable differences were location of the lesion within the stomach (lower body vs. fundus), length of hospital stay ( 7 days vs. 4 days), and procedure time (115 min vs.

\section{Karger'=}




\section{Case Reports in Gastroenterology}

Case Rep Gastroenterol 2021;15:22-27

DOI: 10.1159/000510163

(c) 2021 The Author(s). Published by S. Karger AG, Basel www.karger.com/crg

Okamoto et al.: Crowned Dens Syndrome Occurring after Endoscopic Submucosal Dissection for Early Gastric Cancer

$36 \mathrm{~min}$ ). The second ESD resulted in a shorter hospital stay only because the patient strongly requested early discharge for personal reasons.

On day 6 after the second ESD, the patient woke up with severe neck pain and stiffness. He presented to our outpatient department on day 9 as his symptoms did not improve. He did not recall any triggering events and had no history of neck or joint pain, trauma, or peripheral neuropathy. The pain was a constant, tugging pain of moderate severity in the posterior cervical area which was aggravated by movement. No other joints were affected.

Vital signs were normal and his temperature was $37.0^{\circ} \mathrm{C}$. While he kept his head completely still, he was otherwise in no apparent distress. The patient could nod but could not rotate his head even slightly. His neck also had poor passive range of motion. No neurological abnormalities were noted. Laboratory results were only significant for elevated C-reactive protein of $3.67 \mathrm{mg} / \mathrm{dL}$. All electrolytes including magnesium $(2.2 \mathrm{mg} / \mathrm{dL})$ and parathyroid hormone were within the normal range. Rheumatoid factor and antinuclear antibodies were negative. Computed tomography (CT) of the cervical spine without contrast showed calcifications surrounding the odontoid process (Fig. 2). The patient was diagnosed with CDS.

We prescribed colchicine $1 \mathrm{mg} /$ day and symptoms resolved completely in 3 days. The patient was diagnosed within $2 \mathrm{~h}$ after presentation and was able to avoid admission. No recurrence of CDS or pseudogout in other joints has been seen in 24 months of follow-up without prophylaxis.

\section{Discussion/Conclusion}

CDS is a rare form of acute pseudogout with CPPD deposition surrounding the odontoid process [4]. The differential diagnosis can be broad and a high index of suspicion is required for diagnosis. Initial diagnoses other than CDS are made in about half of the cases, including meningitis, polymyalgia rheumatica, giant cell arteritis, cervical spondylosis, and infective endocarditis $[5,10]$. As the cervical spine cannot be aspirated, CT is used for diagnosis in almost all cases [5].

Known risk factors include old age, prior joint damage, recent surgery, hemochromatosis, hyperparathyroidism, hypomagnesemia, dehydration, and the use of diuretics [2]. While age was a definite risk factor in our case, we speculate that events surrounding the ESD also helped trigger CDS. Limiting fluid intake before and after the procedure causes dehydration, predisposing the patient to CPPD deposition. Hypomagnesemia may have also played a role. Intravenous maintenance fluids given after ESD did not contain magnesium and dietary intake was restricted. PPIs reduce intestinal magnesium absorption and can cause hypomagnesemia, particularly with long-term use [11]. While the serum magnesium level was within the normal range, it is well-established that serum levels do not accurately reflect the total body magnesium content as only $0.3 \%$ of the body's magnesium is distributed to the serum [12]. Symptoms of magnesium deficiency can occur despite a normal serum magnesium level [13].

Our patient underwent 2 very similar gastric ESDs 3 months apart and only experienced CDS after the second ESD. Only the second ESD was preceded by an extended period of PPI use, enhancing the likelihood of hypomagnesemia as a potential trigger. More research is needed to elucidate the causes and prevention of CPPD deposition after ESD.

No existing medications can eliminate CPPD deposition. Symptomatic treatment for acute pseudogout is based on evidence from acute gout attacks [14]. Oral non-steroidal anti-inflammatory drugs (NSAIDs) or low-dose colchicine are generally used, with steroids reserved for

\section{Karger'=}




\section{Case Reports in Gastroenterology}

\begin{tabular}{l|l}
\hline Case Rep Gastroenterol 2021;15:22-27 \\
\hline DOI: 10.1159/000510163 & $\begin{array}{l}\text { @ 2021 The Author(s). Published by S. Karger AG, Basel } \\
\text { www.karger.com/crg }\end{array}$ \\
\hline
\end{tabular}

Okamoto et al.: Crowned Dens Syndrome Occurring after Endoscopic Submucosal Dissection for Early Gastric Cancer

contraindications to the first two medications [15]. Colchicine is a reasonable choice in gastric ESD patients with post-treatment ulcers, which preclude the use of NSAIDs.

There are only 5 reported cases of CDS occurring after endoscopic procedures, possibly due to underdiagnosis. Kohno et al. [8] reported a case of CDS occurring after colonic endoscopic mucosal resection, suggesting bowel preparation with polyethylene glycol as a possible trigger. Nakano et al. [9] reported CDS in 4 octogenarians occurring after endoscopic retrograde cholangiopancreatography, attributing CDS to inflammation and neck position during ERCP. All reported post-endoscopy CDS cases involved elderly patients with an average age of 80.7 years (range: 72-87). CDS occurred an average of 5.5 (range: 1-16) days after the endoscopic procedure and all were diagnosed with CT. As all procedures involve several days of strict dietary restrictions, dehydration and hypomagnesemia may have contributed to the pathogenesis of CDS.

In conclusion, we report the first case of CDS occurring after ESD and the first post-endoscopy case treated with colchicine. A high index of suspicion is required when a patient presents with neck pain after endoscopic procedures. Colchicine is an attractive alternative to NSAIDs for CDS in post-ESD cases. Further studies are required to determine the pathogenesis and whether adequate hydration, magnesium supplementation, or shorter periods of PPI use are helpful in preventing CDS in patients undergoing ESD.

\section{Statement of Ethics}

The patient has given his written informed consent to publish this case (including publication of images). The identity of the patient has been protected.

\section{Conflict of Interest Statement}

The authors have no conflicts of interest to declare.

\section{Funding Sources}

None.

\section{Author Contributions}

Takeshi Okamoto wrote the manuscript, diagnosed the patient, and performed endoscopic procedures. Takashi Ikeya and Katsuyuki Fukuda edited the manuscript. Both gave final approval of the manuscript.

\section{References}

1 Kohn NN, Hughes RE, McCarty Jr DJ, Faires JS. The Significance of Calcium Phosphate Crystals in the Synovial Fluid of Arthritic Patients: The "Pseudogout Syndrome": II. Identification of Crystals. Ann Intern Med. 1962;56(5_Part_1):738-45.

\section{Karger'=}




\section{Case Reports in Gastroenterology}

\begin{tabular}{l|l}
\hline Case Rep Gastroenterol 2021;15:22-27 \\
\hline DOI: 10.1159/000510163 & $\begin{array}{l}\text { @ 2021 The Author(s). Published by S. Karger AG, Basel } \\
\text { www.karger.com/crg }\end{array}$ \\
\hline
\end{tabular}

Okamoto et al:: Crowned Dens Syndrome Occurring after Endoscopic Submucosal Dissection for Early Gastric Cancer

2 Richette P, Bardin T, Doherty M. An update on the epidemiology of calcium pyrophosphate dihydrate crystal deposition disease. Rheumatology (Oxford). 2009 Jul;48(7):711-5.

3 Abreu M, Johnson K, Chung CB, De Lima JE Jr, Trudell D, Terkeltaub R, et al. Calcification in calcium pyrophosphate dihydrate (CPPD) crystalline deposits in the knee: anatomic, radiographic, MR imaging, and histologic study in cadavers. Skeletal Radiol. 2004 Jul;33(7):392-8.

4 Bouvet JP, le Parc JM, Michalski B, Benlahrache C, Auquier L. Acute neck pain due to calcifications surrounding the odontoid process: the crowned dens syndrome. Arthritis Rheum. 1985 Dec;28(12):141720.

5 Oka A, Okazaki K, Takeno A, Kumanomido S, Kusunoki R, Sato S, et al. Crowned Dens Syndrome: Report of Three Cases and a Review of the Literature. J Emerg Med. 2015 Jul;49(1):e9-13.

6 O’Duffy JD. Pseudogout syndrome in hospital patients. JAMA. 1973 Oct;226(1):42-4.

7 Mehta BP, Shmerling RH, Moss AC. Pseudogout after polyethylene glycol bowel cleansing. J Clin Gastroenterol. 2009 Jan;43(1):95-6.

8 Kohno N, Kobori Y, Yamaguchi S. Crowned Dens Syndrome Associated with Bowel Cleaning for Colonoscopy. Intern Med. 2017 Oct;56(19):2645-7.

9 Nakano H, Nakahara K, Michikawa Y, Suetani K, Morita R, Matsumoto N, et al. Crowned dens syndrome developed after an endoscopic retrograde cholangiopancreatography procedure. World J Gastroenterol. 2016 Oct;22(39):8849-52.

10 Godfrin-Valnet M, Godfrin G, Godard J, Prati C, Toussirot E, Michel F, et al. Eighteen cases of crowned dens syndrome: presentation and diagnosis. Neurochirurgie. 2013 Jun;59(3):115-20.

11 Kieboom BC, Kiefte-de Jong JC, Eijgelsheim M, Franco OH, Kuipers EJ, Hofman A, et al. Proton pump inhibitors and hypomagnesemia in the general population: a population-based cohort study. Am J Kidney Dis. 2015 Nov;66(5):775-82.

12 Elin RJ. Assessment of magnesium status. Clin Chem. 1987 Nov;33(11):1965-70.

13 Reinhart RA. Magnesium metabolism. A review with special reference to the relationship between intracellular content and serum levels. Arch Intern Med. 1988 Nov;148(11):2415-20.

14 Macmullan P, McCarthy G. Treatment and management of pseudogout: insights for the clinician. Ther Adv Musculoskelet Dis. 2012 Apr;4(2):121-31.

15 Zhang W, Doherty M, Pascual E, Barskova V, Guerne PA, Jansen TL, et al. EULAR recommendations for calcium pyrophosphate deposition. Part II: management. Ann Rheum Dis. 2011 Apr;70(4):571-5.
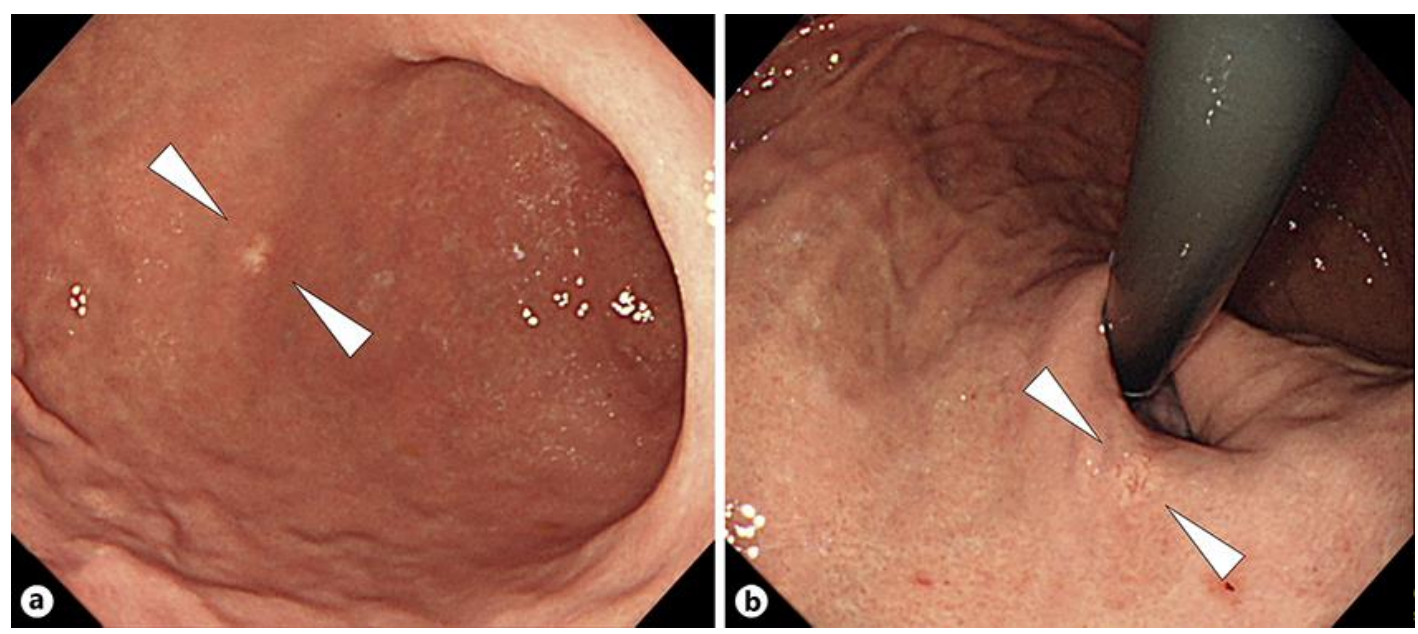

Fig. 1. Two similar gastric lesions discovered on routine endoscopy. One lesion (arrowheads) located on the anterior wall of the lower body (a) was treated by ESD 3 months prior to the onset of neck pain. The other lesion (arrowheads) located at the fundus of the stomach (b) was treated by ESD 6 days prior to the onset of neck pain.

\section{Karger'=}


Case Reports in Gastroenterology
Case Rep Gastroenterol 2021;15:22-27

DOI: $10.1159 / 000510163$

(c) 2021 The Author(s). Published by S. Karger AG, Basel www.karger.com/crg

Okamoto et al:: Crowned Dens Syndrome Occurring after Endoscopic Submucosal Dissection for Early Gastric Cancer
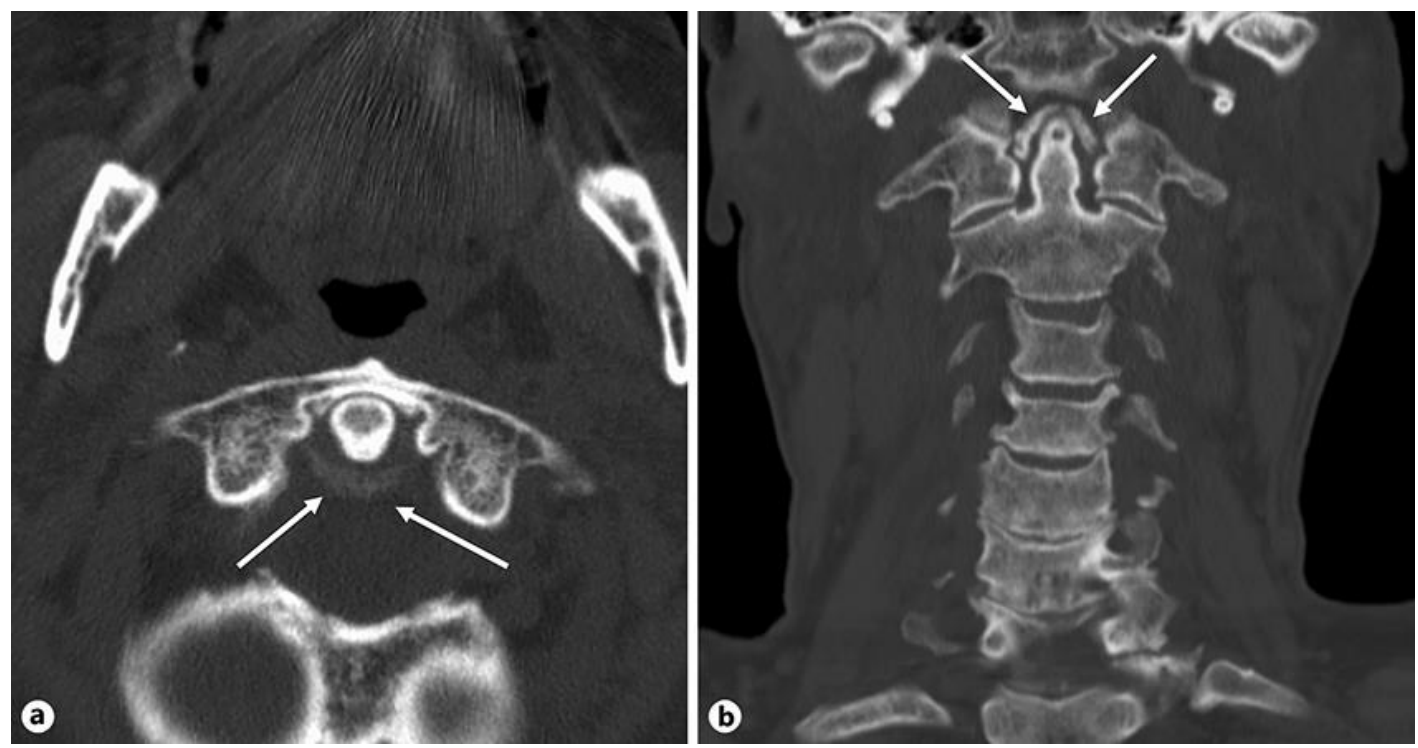

Fig. 2. Axial (a) and coronal (b) views of cervical CT with calcifications (arrows) surrounding the odontoid process presenting a crown-like appearance. 